\title{
Comparative results of percutaneous cannulated screws, dynamic compression type plate and screw for the treatment of femoral neck fractures
}

\author{
Femur boyun kırıklarının tedavisinde perkütan kanüle vida, \\ dinamik kompresyon plak ve vidanın karşılaştırmalı sonuçları
}

\author{
Tolga KAPLAN, ${ }^{1}$ Burak AKESEN, ${ }^{2}$ Burak DEMİRAĞ,${ }^{2}$ Sadık BİLGEN, ${ }^{2}$ Kemal DURAK ${ }^{2}$
}

\section{BACKGROUND}

The purpose of this study was to compare the period of union, functional outcomes and complications of patients with femoral neck fracture treated with percutaneous cannulated screws versus dynamic hip screw (DHS).

\section{METHODS}

Sixty-six patients with femoral neck fracture were treated with percutaneous cannulated screws $(n=33)$ or with DHS $(n=33)$ between August 1999 and October 2003. Functional outcome was measured using Harris Hip Score, and period of union, amount of bleeding and complications were also recorded.

\section{RESULTS}

The period of union and functional outcomes were not different between the two groups. Risk of avascular necrosis (AVN) was associated mainly with the grade of fracture displacement. In the percutaneous cannulated screw group, duration of surgery was shorter and blood loss was less than in the other group.

\section{CONCLUSION}

There was no superiority between cannulated screws and DHS according to union times and functional results. Risk of AVN is related to the degree of displacement. However, a prospective randomized study is needed to determine the outcome of each technique for patients suffering similar displacement rates.

Key Words: Dynamic hip screw; fractures of the femoral neck; percutaneous; cannulated screw.

\section{AMAÇ}

$\mathrm{Bu}$ çalışmanın amacı, perkütan kanüle vida veya dinamik kalça vidası (DKV) ile tedavi edilen femur boyun kırıklı hastaların kaynama süresi, fonksiyonel sonuçlar ve komplikasyonlar açısından karşılaştırılmasıdır.

\section{GEREÇ VE YÖNTEM}

Ağustos 1999 ile Ekim 2003 tarihleri arasında femur boyun kırığı bulunan altmış altı hasta perkütan kanüle vida $(n=33)$ veya DKV $(n=33)$ ile tedavi edildi. Fonksiyonel sonuçlar Harris kalça skoru ile değerlendirildi. Çalışmada ayrıca kayanama süreleri, kanama miktarı ve komplikasyon oranı ölçüldü.

\section{BULGULAR}

Kaynama süreleri ve fonksiyonel sonuçlar açısından iki grup arasında anlamlı fark bulunmadı. Avasküler nekroz riski en çok kırığın kayma miktarı ile ilişkili bulundu. Perkütan kanüle vida uygulanan grupta ameliyat süresi ve kanama miktarı anlamlı olarak daha düşük bulundu.

\section{SONUÇ}

Kayanama süresi ve fonksiyonel sonuç açısından perkütan kanüle vida ve DKV uygulamarının birbirlerine üstünlüğü bulunmamaktadır. Avasküler nekroz riski kırığın kayma miktarı ile ilişkilidir. Bununla birlikte aynı kayma miktarı bulunan hastlarda iki tekniğin birbirleri ile karşılaştırılması için prospektif randomize bir çalışma gereksinimi vardir.

Anahtar Sözcükler: Dinamik kalça vidası; femur boyun kırığı; perkütan; kanüle vida.

\footnotetext{
${ }^{1}$ Department of Orthopaedics and Traumatology, Medical Park Hospital, Bursa; ${ }^{2}$ Department of Orthopaedics and Traumatology,
} Uludag University Faculty of Medicine, Bursa, Turkey.

${ }^{1}$ Medical Park Hastanesi, Ortopedi ve Travmatoloji Kliniği, Bursa; ${ }^{2}$ Uludağ Üniversitesi Tıp Fakültesi, Ortopedi ve Travmatoloji Anabilim Dalı, Bursa. 
The incidence of proximal femoral fractures tends to increase among the elderly as mean lifespan continues to increase. Increases in high-energy traffic accidents and popularization of extreme sports that exert limits make the young population also prone to such fractures. ${ }^{[1-6]}$ One percent of all fractures occur around the femoral neck. ${ }^{[7]}$ These fractures most commonly occur in individuals over 50 years of age. ${ }^{[8]}$ Approximately $2-3 \%$ of femoral neck fractures occur in the population below 50 years of age ${ }^{[9]}$ Due to the distinguished arterial nutrition of the femoral head, avascular necrosis (AVN) is a common complication following these fractures. ${ }^{[10,11]}$

Early anatomical reduction and stable fixation prevent complications like AVN of the femoral head and non-union, especially in young patients. ${ }^{[6,8,12]}$ Direct or indirect stress may cause femoral neck fractures. ${ }^{[7]}$ In the indirect mechanism, fracture may occur due to the leaning of the femoral head against the acetabulum, with the effect of fourth forces when the thigh is in abduction. Falling on the greater trochanter when the thigh is in semi-flexion may cause fractures of the femoral neck by indirect forces. ${ }^{[13]}$

In this study, we retrospectively evaluated the early-mid-term results of femoral neck fractures surgically treated by internal fixation with either percutaneous cannulated screws or dynamic hip screw (DHS).

\section{MATERIALS AND METHODS}

Sixty-six patients (31 female, 35 male) with femoral neck fractures who were treated surgically with either percutaneous cannulated screws or DHS between August 1999 and October 2003 in our institution were enrolled in this retrospective study. The presence of multiple fractures, associated chest, abdominal or head injuries, and concurrent systemic diseases such as chronic renal failure, rheumatoid arthritis, systemic lupus erythematosus and malignancy were regarded as the exclusion criteria to this particular study. The
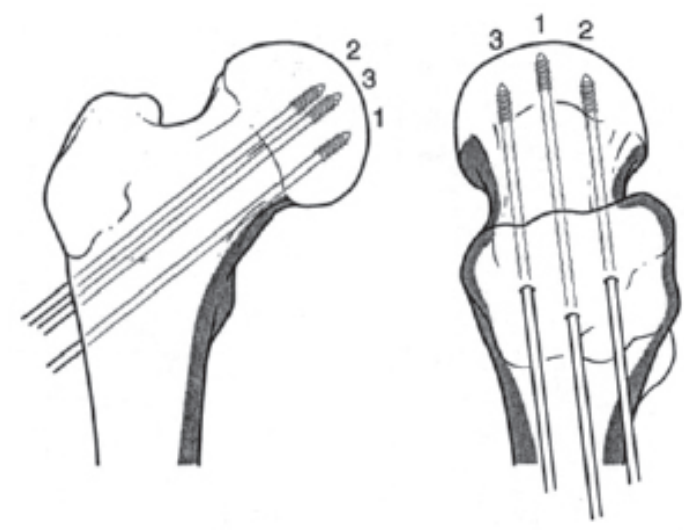

Fig. 2. Steps of cannulated screw application.

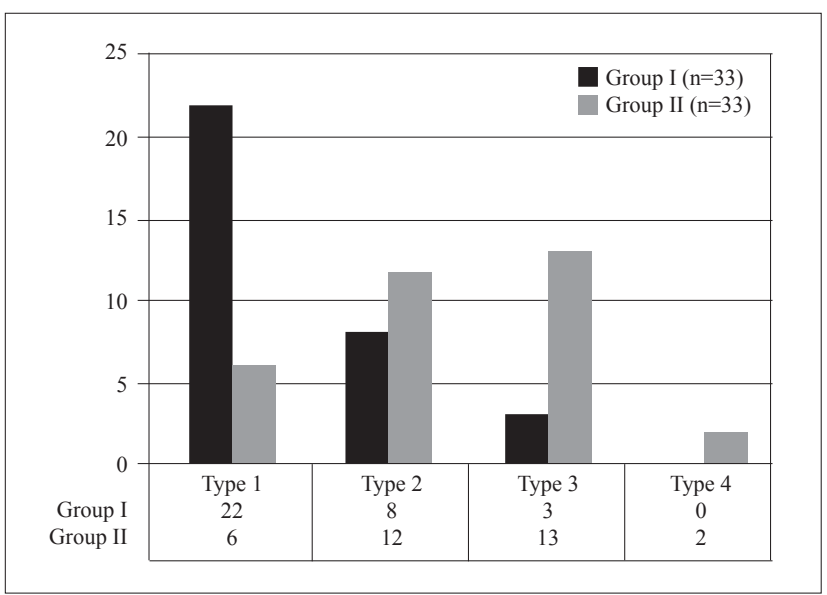

Fig. 1. Distribution of fracture types in Groups I and II.

patients were grouped according to the internal fixation devices used. Thirty-three patients operated with cannulated screws were regarded as Group I and 33 patients operated with DHS as Group II. The mean age of the patients at the time of surgery was 45 years (range: 18-68) in Group I and 46 years (range: 25-67) in Group II. According to the Garden's classification, 28 patients were type I, 20 were type II, 16 type III, and 2 were type IV (Fig. 1).

All patients received intravenous cefazolin sodium $(1 \mathrm{~g})$ and gentamicin sulfate $(80 \mathrm{mg})$ before the operation and for three days after surgery. Low molecular weight heparin was administered to prevent deep vein thrombosis before the surgery and was continued for 21 days after surgery. Under regional or general anesthesia, closed hip reduction was ensured for patients in Group I under sterile conditions in the supine position followed by percutaneous fixation with three $7.3 \mathrm{~mm}$ cannulated screws. The first screw was applied inferiorly in the femoral neck, the second screw near the posterior cortex and the third in the anterior side of the femoral neck; all screws were in parallel position (Figures 2, 3). ${ }^{[14,15]}$

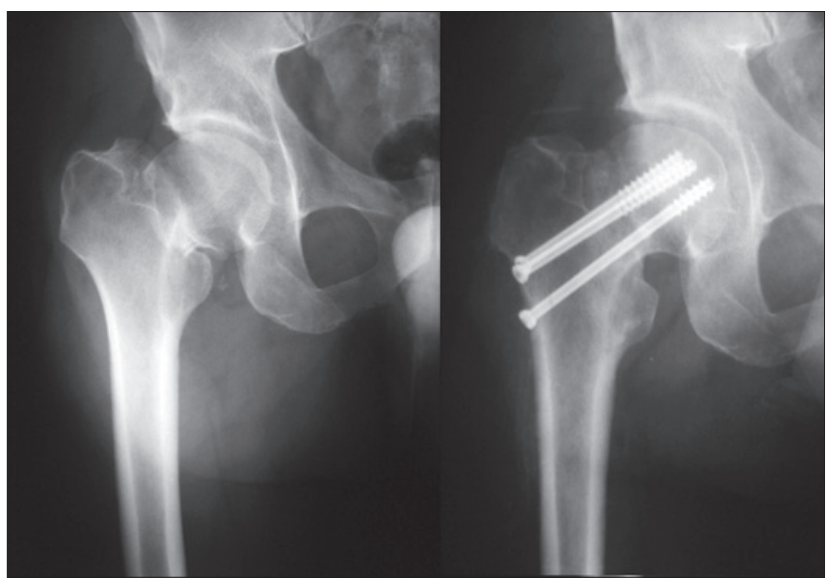

Fig. 3. Pre- and postoperative direct radiographs of a patient treated with cannulated screws. 


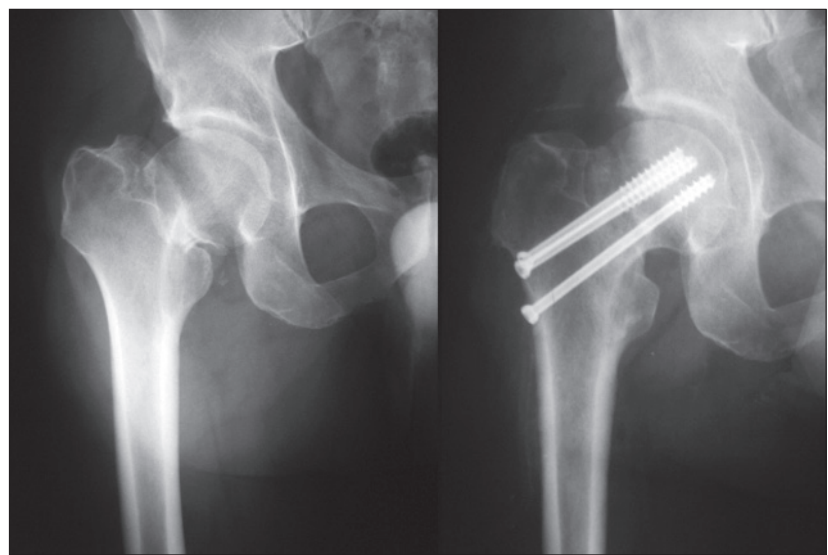

Fig. 4. Pre- and postoperative direct radiographs of a patient treated with DHS.

The proximal femur was exposed through the lateral approach in patients of Group II in the supine position. After fracture reduction under $\mathrm{C}$-arm control without capsulotomy, fixation was achieved by DHS as in the original technique. One spongiosa screw was inserted as an anti-rotation screw (Fig. 4).

Operation times, amount of bleeding and need for transfusion in all patients were recorded. All patients were mobilized in the first day after the operation, without weight- bearing on the operated hip using crutches or walker. When follow-up radiographs showed sufficient healing and a pain-free hip was achieved clinically, patients were permitted controlled partial weight-bearing initially and full weight-bearing later, using crutches for four months. Patients were called for radiological follow-up and physical examination postoperatively in the $1 \mathrm{st}, 3 \mathrm{rd}, 6 \mathrm{th}$, and 12 th months and once a year thereafter. The scoring system of Pennsylvania University ${ }^{[16]}$ and Garden Alignment In$\mathrm{dex}^{[17]}$ were utilized for radiological evaluation. Functional results were calculated by Harris Hip Score. ${ }^{[18]}$ For statistical comparison of groups, Student's t-test was used for parametric dispersions and Mann-Whitney U test, Fisher's exact test and chi-square test for nonparametric dispersions.

\section{RESULTS}

There was no significant difference statistically between operation times, blood loss during surgery, non-union rates, malalignments, AVN occurrence, and Harris Hip Scores of groups according to age and gender properties $(\mathrm{p}>0.05)$. Mean follow-up time was 33.6 months (range: $7-57$ ) for all patients, 34.5 months (range: 7-57) for Group I, and 32.6 months (range: 8853) for Group II. The mechanisms of injury were classified as outdoor fall, indoor fall, fall from a height, fall from stairs, crush injury, traffic accident inside vehicle, and traffic accident outside vehicle, and they are summarized in Fig. 5.
According to Garden's classification, $66.7 \%$ of patients in Group I were type I, while 39.3\% and 36.3\% of patients in Group II were type III and type II, respectively (Fig. 1). When the relationship between mechanism of injury and fracture type was evaluated, type I fractures were seen more frequently after a fall on stairs in both groups $(p<0.005)$. Mean preoperative durations were 10123 hours (range: 1-120) in Group I, and 41 hours (range: 6-240) in Group II. Mean preoperative duration as a variable did not cause any significant difference between groups statistically according to the occurrence of AVN ( $p>0.05$ ). Mean operation time was 46 minutes (range: 15-60) in Group I and 95 minutes (range: 50-240) in Group II. There was a significant difference between groups according to operation times $(\mathrm{p}<0.001)$. The amount of bleeding during the operation was $168 \mathrm{cc}$ (range: 50-110) in Group I and 653 cc (range: 250-1120) in Group II. There was a statistically significant difference between groups according to blood loss during surgery $(\mathrm{p}<0.001)$. The mean healing time was 4 months (range: 3-5.1). The union rate was $97 \%$ in Group I and 91\% in Group II. These rates did not reveal any significant difference statistically $(\mathrm{p}>0.05)$. In Group I, evaluation of early and late complications revealed superficial wound infection of the incision site in 1 patient, a broken screw in 2 patients, and nonunion in 1 patient. Repeated trauma was detected in the postoperative second month in 2 patients who had broken cannulated screws. In these patients, fixation was revised with DHS. Union was achieved in both patients at the 6th month. For the patient who had non-union, cannulated screws were removed in the 8th month and Dickson ${ }^{[19]}$ geometric osteotomy and fixation with DHS were performed. Union was achieved five months after the second operation in this patient. In Group II, 6 patients had various complications: deep vein thrombosis (1 patient), implant failure (2 patients), and non-union (3 patients). After consultation

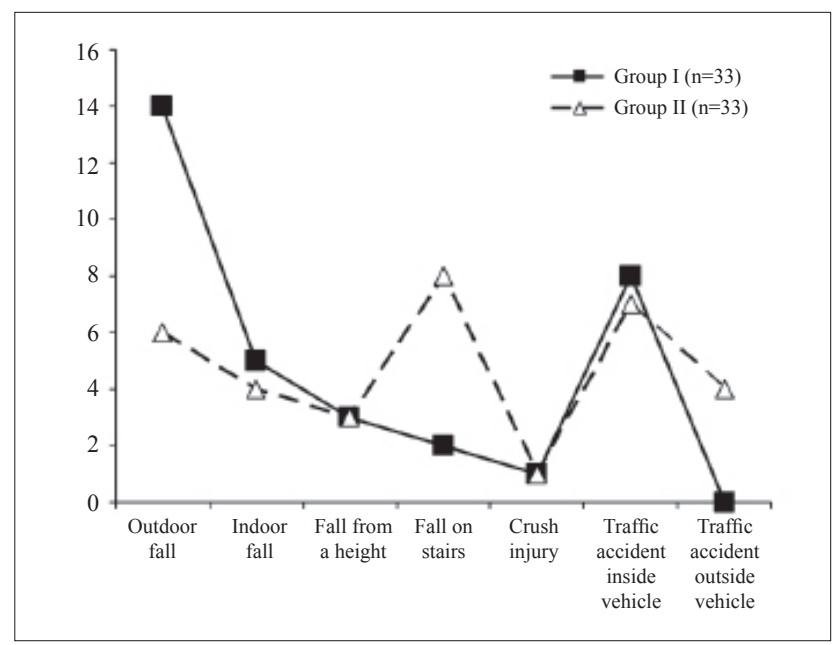

Fig. 5. Mechanisms of injury of patients in Groups I and II. 
with the Cardiovascular Surgery Department, proper medical treatment was begun for deep vein thrombosis of the patient. Implant failure occurred because of early uncontrolled weight-bearing in 2 patients. The one who had loosening of the compression screw was taken to the operating room and the screw was tightened. In the other patient, loosening of the plate screw and loss of reduction were detected. In this patient, Dickson $^{[19]}$ geometric osteotomy and fixation with DHS were performed. Union was achieved four months after the second operation. Non-union was detected in 3 patients. Hemiarthroplasty was performed for a 64-year-old patient in whom non-union was detected eight months after the first operation. In the second patient, autogenous grafting was done, and in the last patient, Dickson ${ }^{[19]}$ geometric osteotomy and fixation with DHS were performed. The grafted fracture united in two months and the other in five months. According to these complication rates, there was no statistically significant difference between groups $(\mathrm{p}>0.05)$. When AVN rates were evaluated, stage II or more advanced AVN was detected in $18 \%$ of patients in Group I and in $30 \%$ of patients in Group II. Patients who had this complication were operated 14 hours (range: 2 -48) after the trauma in Group I and 20 hours (range: 8-48) after the trauma in Group II. Among these patients, fracture types according to Garden's classification system were as follows: in Group I, 1 patient type I, 2 patients type II and 3 patients type III, and in Group II, 1 patient type II, 1 patient type IV and 8 patients type III. Mean time for diagnosis of AVN was 13 months (range: 9-21) in Group I and 8.6 months (range: 6-13) in Group II. Implants were removed in all patients of both groups who had a diagnosed AVN. Variables of age, gender, mechanism of injury, side of the fracture, American Society of Anesthesiologists (ASA) score, and preoperative waiting time did not cause any statistically significant difference between groups according to the occurrence of AVN ( $p>0.05)$. When the relationship between fracture type and occurrence of AVN was investigated, AVN frequency was greater in displaced fractures in both groups $(\mathrm{p}<0.001)$. When radiological results were evaluated, Garden Alignment Index ${ }^{[17]}$ was $162^{\circ}$ (range: $155^{\circ}-170^{\circ}$ ) in Group I and $163^{\circ}$ (range: $155^{\circ}-170^{\circ}$ ) in Group II, and there was no significant difference between groups according to malalignment statistically $(\mathrm{p}>0.05)$. Evaluation of functional results according 151 to Harris ${ }^{[18]}$ criteria revealed $91 \%$ excellent and good results, $6 \%$ fair and $3 \%$ bad results in Group I. Mean Harris ${ }^{[18]}$ Hip Score in this group was 91 (range: 65-100). In Group II, the proportion of excellent and good results was $85 \%$ and of fair results $15 \%$, and the mean Harris ${ }^{[18]}$ Hip Score was 90 (range: 75-99). The patient with a bad result in Group I was known to have a broken screw and revision surgery with DHS; 2 patients with fair results in
Group I were complicated by AVN. In Group II, 1 of 5 patients with a fair result was re-operated because of non-union and the other 4 had AVN. There was no significant difference between groups statistically according to functional results $(\mathrm{p}>0.05)$.

\section{DISCUSSION}

The main aim in the treatment of a femoral neck fracture is to facilitate a patient's return to his normal activities as soon as possible. Internal fixation of these fractures is more important than arthroplasties today, because the patient's native bone tissue is used and low costs are achieved..$^{[6,20-25]}$ While selecting a treatment method for these fractures, determination of the patient's physiological and chronological age is important along with determination of fracture type. Femoral neck fractures in the young population must be treated immediately and internal fixation must be performed after closed reduction. ${ }^{[26-29]}$ In the elderly, sufficient bone stock is needed for internal fixation, and functional status before fracture must be kept in mind to select a treatment method. ${ }^{[6,22,30,31]}$ Various types of fixation devices are reported for stabilization of femoral neck fractures. ${ }^{[32]}$ The most important factor in selecting an implant is that it uses a minimally invasive technique and protects the vascular supply of the femoral head by preventing additional soft tissue injury. The implants that fit these criteria are cannulated screws and DHS, which we used in our study. ${ }^{[15,22,33,34]}$ As Garden classification is based on displacement of the 176 fractures, it has a strong effect on decision-making about the treatment option and prognosis. ${ }^{[35,36]}$ In both groups, type I fractures were detected frequently after falling on stairs and the relationship was significant statistically $(\mathrm{p}<0.05)$. When evaluated according to the mechanism of injury, we think that undisplaced impaction fractures occur when the lateral side of the hip hits the edge of the stair during the fall. Our study revealed a difference between groups regarding operation times $(\mathrm{p}<0.001)$. In Group I, application of percutaneous screws lasted 46 minutes (range: 15-60). In Group II, the duration of DHS application was 95 minutes (range: 50-140). The percutaneous cannulated screw fixation method, which has lower operation times, also shortens anesthesia time and prevents the possible complications of anesthesia. Blood loss during cannulated screw fixation in Group I was lower than in the other group in which DHS was applied $(\mathrm{p}<0.001)$. It was also reported by Swiontkowski and Winquist ${ }^{[37]}$ that use of cannulated screws for femoral neck fractures causes lower blood loss during operation. Madsen et al. ${ }^{[38]}$ reported that application of DHS for these fractures causes prolonged operation and more blood loss, which supports the results of our study. In our study, there was no difference between groups according to occurrence of AVN ( $>>0.05)$, and 
this complication was seen more in displaced fractures in both groups $(\mathrm{p}>0.05)$. Swiontkowski et al. ${ }^{[26]}$ reported AVN rates of $20 \%$ in femoral neck fractures treated by cannulated screws, and they emphasized that this complication occurred in displaced fractures more frequently. This proportion is similar in Group I in our study, at $18 \%$. However, there are studies that report $8-16 \% \mathrm{AVN}$ in similar type of fractures. ${ }^{[5,30,39-41]}$ Barnes et al. ${ }^{[8]}$ reported an AVN rate of $22 \%$ and Ort et al. ${ }^{[42]}$ reported an AVN rate of $24 \%$ in femoral neck fractures treated by DHS. We found higher rates $(30 \%$ in our Group II patients with DHS), which may have been caused by selection bias. Zuckerman et al. ${ }^{[43]}$ reported that this complication 201 will occur at an $11 \%$ lower rate in patients who are operated in the first 48 hours, regardless of the fixation technique used. Mean union time of all fractures was four months. Unlike our results, Shih and Wang ${ }^{[44]}$ reported a union time of six months in 121 patients with a mean age of 36.8 . Rodrique $^{[45]}$ reported a $95 \%$ union rate after fixation with cannulated screws, and Ort et al. ${ }^{[42]}$ reported a $90.4 \%$ union rate after fixation of femoral neck fractures with DHS. Similarly, we found union rates of 97\% and $91 \%$ in Groups I and II, respectively. We did not find any difference between groups according to union problems in our study ( $\mathrm{p}>0.05)$. Non-union rates were $3 \%$ and $9 \%$ in Groups I and II, respectively. We think that the difference is a result of more displaced fractures scheduled in Group II rather than the fixation method used. The study of Frandsen et al. ${ }^{[46]}$ supports our opinion, in that they found non-union problems more frequent in displaced fractures. As a result, the first choice of treatment for fractures of the femoral neck in young adults and older patients with good bone quality is anatomical reduction; internal fixation, cannulated screws and DHS show no superiority according to union times and functional results. Risk of AVN is related to the degree of displacement. Blood loss was significantly lower in Group I patients, as the cannulated screws were applied percutaneously. However, the decision of hardware to be implanted should be based on the anatomical features of the fracture and biomechanics. In Group II patients, DHS was applied through a longer incision and the operation time was longer. This may explain the difference between the two groups in terms of blood loss. However, a prospective randomized study is needed to determine the outcome of each technique for patients suffering similar displacement rates.

\section{REFERENCES}

1. Holmberg S, Thorngren KG. Statistical analysis of femoral neck fractures based on 3053 cases. Clin Orthop Relat Res 1987:32-41.

2. Jarnlo GB, Thorngren KG. Background factors to hip fractures. Clin Orthop Relat Res 1993;287:41-9.

3. Hedlund R, Lindgren U, Ahlbom A. Age- and sex-specific in- cidence of femoral neck and trochanteric fractures. An analysis based on 20,538 fractures in Stockholm County, Sweden, 1972-1981. Clin Orthop Relat Res 1987;222:132-9.

4. Askin SR, Bryan RS. Femoral neck fractures in young adults. Clin Orthop Relat Res 1976;114:259-64.

5. Lu-Yao GL, Keller RB, Littenberg B, Wennberg JE. Outcomes after displaced fractures of the femoral neck. A metaanalysis of one hundred and six published reports. J Bone Joint Surg Am 1994;76:15-25.

6. Shah AK, Eissler J, Radomisli T. Algorithms for the treatment of femoral neck fractures. Clin Orthop Relat Res 2002;399:28-34. CrossRef

7. Kyle RF. Fractures of the proximal part of the femur. J Bone Joint Surg Am 1994;76:924-50.

8. Barnes R, Brown JT, Garden RS, Nicoll EA. Subcapital fractures of the femur. A prospective review. J Bone Joint Surg Br 1976;58:2-24.

9. Zetterberg C, Elmerson S, Andersson GB. Epidemiology of hip fractures in Göteborg, Sweden, 1940-1983. Clin Orthop Relat Res 1984;191:43-52.

10. Gautier E, Ganz K, Krügel N, Gill T, Ganz R. Anatomy of the medial femoral circumflex artery and its surgical implications. J Bone Joint Surg Br 2000;82:679-83. CrossRef

11. Catto M. A histological study of avascular necrosis of the femoral head after transcervical fracture. J Bone Joint Surg Br 1965;47:749-76.

12. Garden RS: Stability and union in subcapital fractures of the femur. J Bone Joint Surg Br 1964;46:630-47.

13. Aharonoff GB, Dennis MG, Elshinawy A, Zuckerman JD, Koval KJ. Circumstances of falls causing hip fractures in the elderly. Clin Orthop Relat Res 1998;348:10-4. CrossRef

14. Kyle RF, Cabanela ME, Russell TA, Swiontkowski MF, Winquist RA, Zuckerman JD, et al. Fractures of the proximal part of the femur. Instr Course Lect 1995;44:227-53.

15. Bout CA, Cannegieter DM, Juttmann JW. Percutaneous cannulated screw fixation of femoral neck fractures: the three point principle. Injury 1997;28:135-9. CrossRef

16. Steinberg ME, Hayken GD, Steinberg DR. A quantitative system for staging avascular necrosis. J Bone Joint Surg Br 1995;77:34-41.

17. Garden RS. Malreduction and avascular necrosis in subcapital fractures of the femur. J Bone Joint Surg Br 1971;53:18397.

18. Johnston RC, Fitzgerald RH Jr, Harris WH, Poss R, Müller ME, Sledge CB. Clinical and radiographic evaluation of total hip replacement. A standard system of terminology for reporting results. J Bone Joint Surg Am 1990;72:161-8.

19. DeLee CJ. Fractures and dislocations of the hip. Fractures of the neck of the femur. In: Rockwood AC, Green PD, Bucholz WR, editors. Fractures in adults. 3th ed. Philaedelphia: JB. Lippincott Company; 1991. p. 1481-538.

20. Schmidt AH, Swiontkowski MF. Femoral neck fractures. Orthop Clin North Am 2002;33:97-111, viii. CrossRef

21. Eisler J, Cornwall R, Strauss E, Koval K, Siu A, Gilbert M. Outcomes of elderly patients with nondisplaced femoral neck fractures. Clin Orthop Relat Res 2002;399:52-8.

22. Bosch U, Schreiber T, Krettek C. Reduction and fixation of displaced intracapsular fractures of the proximal femur. Clin Orthop Relat Res 2002;399:59-71. CrossRef

23. Thorngren KG, Ceder L, Svensson K. Predicting results of rehabilitation after hip fracture. A ten-year follow-up study. Clin Orthop Relat Res 1993;287:76-81.

24. Pryor GA, Williams DR. Rehabilitation after hip fractures. 
Home and hospital management compared. J Bone Joint Surg Br 1989;71:471-4.

25. Holmberg S, Kalén R, Thorngren KG. Treatment and outcome of femoral neck fractures. An analysis of 2418 patients admitted from their own homes. Clin Orthop Relat Res 1987;218:42-52.

26. Swiontkowski MF. Current concept review: Intracapsuler fractures of the hip. J Bone Joint Surg 1994;76A:129-38.

27. Cserháti P, Kazár G, Manninger J, Fekete K, Frenyó S. Nonoperative or operative treatment for undisplaced femoral neck fractures: a comparative study of 122 non-operative and 125 operatively treated cases. Injury 1996;27:583-8.CrossRef

28. Raaymakers EL, Marti RK. Non-operative treatment of impacted femoral neck fractures. A prospective study of 170 cases. J Bone Joint Surg Br 1991;73:950-4.

29. Strömqvist B, Hansson LI, Nilsson LT, Thorngren KG. Hookpin fixation in femoral neck fractures. A two-year follow-up study of 300 cases. Clin Orthop Relat Res 1987;218:58-62.

30. Hudson JI, Kenzora JE, Hebel JR, Gardner JF, Scherlis L, Epstein RS, et al. Eight-year outcome associated with clinical options in the management of femoral neck fractures. Clin Orthop Relat Res 1998;348:59-66.CrossRef

31. Springer RE, Lachiewicz FP, Gilbert J: Internal fixation of femoral neck fractures. Clin Orthop 1991;267:85-91.

32. Estrada LS, Volgas DA, Stannard JP, Alonso JE. Fixation failure in femoral neck fractures. Clin Orthop Relat Res 2002;399:110-8.CrossRef

33. Blair B, Koval KJ, Kummer F, Zuckerman JD. Basicervical fractures of the proximal femur. A biomechanical study of 3 internal fixation techniques. Clin Orthop Relat Res 1994;306:256-63.

34. Bray TJ. Femoral neck fracture fixation. Clinical decision making. Clin Orthop Relat Res 1997;339:20-31.CrossRef

35. Parker MJ. Garden grading of intracapsular fractures: meaningful or misleading? Injury 1993;24:241-2.CrossRef

36. Frandsen PA, Andersen E, Madsen F, Skjødt T. Garden's classification of femoral neck fractures. An assessment of inter-observer variation. J Bone Joint Surg Br 1988;70:58890.

37. Swiontkowski MF, Winquist RA. Displaced hip fractures in children and adolescents. J Trauma 1986;26:384-8.CrossRef

38. Madsen F, Linde F, Andersen E, Birke H, Hvass I, Poulsen TD. Fixation of displaced femoral neck fractures. A comparison between sliding screw plate and four cancellous bone screws. Acta Orthop Scand 1987;58:212-6.CrossRef

39. Asnis SE, Wanek-Sgaglione L. Intracapsular fractures of the femoral neck. Results of cannulated screw fixation. J Bone Joint Surg Am 1994;76:1793-803.

40. Parker MJ, Porter KM, Eastwood DM, Schembi Wismayer $\mathrm{M}$, Bernard AA. Intracapsular fractures of the neck of femur. Parallel or crossed garden screws? J Bone Joint Surg Br 1991;73:826-7.

41. Swiontkowski MF, Winquist RA, Hansen ST Jr. Fractures of the femoral neck in patients between the ages of twelve and forty-nine years. J Bone Joint Surg Am 1984;66:837-46.

42. Ort PJ, LaMont J. Treatment of femoral neck fractures with a sliding compression screw and two Knowles pins. Clin Orthop Relat Res 1984;190:158-62.

43. Zuckerman JD, Skovron ML, Koval KJ, Aharonoff G, Frankel VH. Postoperative complications and mortality associated with operative delay in older patients who have a fracture of the hip. J Bone Joint Surg Am 1995;77:1551-6.

44. Shih CH, Wang KC. Femoral neck fractures. 121 cases treated by Knowles pinning. Clin Orthop Relat Res 1991;271:195200.

45. Rodríguez-Merchán EC. In situ fixation of nondisplaced intracapsular fractures of the proximal femur. Clin Orthop Relat Res 2002;399:42-51.CrossRef

46. Frandsen PA, Andersen PE Jr, Christoffersen H, Thomsen PB. Osteosynthesis of femoral neck fracture. The slidingscrew-plate with or without compression. Acta Orthop Scand 1984;55:620-3.CrossRef 